\title{
Primary Urothelial Carcinoma of the Anterior Urethra
}

\author{
Anterior Üretranın Primer Ürotelyal Karsinomu
}

\author{
(1) McGeorge Stephen ${ }^{1}$, (1) Desai Devang22, (1) Saxena Maneesha3 \\ ${ }^{1}$ Toowoomba Hospital, Clinic of Urology, Queensland, Australia \\ 2University of Queensland, Department of Urology, Australia \\ 3 Toowoomba Hospital, Clinic of Anatomical Pathology, Queensland, Australia
}

\begin{abstract}
We report the case of an 89-year-old male with an isolated anterior urethral invasive urothelial carcinoma. This is a rare primary tumour of the anterior urethra, as this area is not lined by urothelium. It was managed with radical penectomy and perineal urethrostomy, and the patient has no recurrence to date.
\end{abstract}

Keywords: Urothelial carcinoma, Urethra, Penectomy

\section{Öz}

İzole ön üretral invaziv ürotelyal karsinomu olan 89 yaşında bir erkek olguyu sunuyoruz. Bu, anterior üretranın nadir görülen primer tümörüdür, çünkü bu bölge ürothelium ile kaplı değildir. Bu radikal penektomi ve perineal üretrostomi ile tedavi edildi ve hastanın bugüne kadar nüksü olmadı. Anahtar Kelimeler: Ürotelyal karsinom, İdrar yolu, Penektomi

\section{Introduction}

Primary urethral carcinoma is very rare, being less than one per cent of urological malignancy, and only a small proportion of this is urothelial carcinoma, which is predominantly seen in the posterior urethra $(1,2,3)$. Primary urothelial carcinoma of the anterior urethra is unusual because this area is not normally lined by urothelium. Postulated mechanisms include the presence of foci of ectopic urothelium or metaplastic change (4). One case in 2006 detected human papillomavirus (HPV) type 16 in a grade 3 urothelial carcinoma of the fossa navicularis, suggesting that HPV may play a role in development of urothelial carcinoma particularly in immunosuppressed patients and that this may also be influenced by dissemination via urethral instrumentation (3). However, this role is likely a minor one (5).

\section{Case Presentation}

An 89-year-old man was referred for painless macroscopic haematuria and obstructive lower urinary tract symptoms. He was a lifelong non-smoker, with no significant family history or risk factors for urothelial carcinoma. Abdominal examination was unremarkable, external genitalia were normal and the prostate was small and firm. There was no palpable inguinal lymphadenopathy.

Urine cytology showed small clusters of highly atypical urothelial cells with large numbers of atypical spindled cells with dense orangeophilic cytoplasm, suspicious for highgrade urothelial carcinoma with squamous differentiation. Computed tomography (CT) urography showed no upper tract abnormalities.

Rigid cystourethroscopy found a solid pale tumour in the penile urethra, almost entirely occluding the lumen (Figure 1). A guidewire was passed beyond the tumour, which was then debulked, however, poor visibility prevented adequate examination of the bladder and a catheter was left in situ. Histology showed high-grade papillary urothelial carcinoma with no invasion seen.

Three weeks later, repeat rigid cystourethroscopy showed circumferential polypoid tumour involving a five centimetres

Correspondence: Desai Devang MD, Toowoomba Hospital, Clinic of Urology, Queensland, Australia

E-mail: ddesai@toowoombaurology.com.au ORCID-ID: orcid.org/0000-0002-1937-936X

Received: 19.06.2019 Accepted: 03.08.2019

Cite this article as: Stephen M, Devang D, Maneesha S. Primary Urothelial Carcinoma of the Anterior Urethra. J Urol Surg 2019;6(4):347-348.

${ }^{\circ}$ Copyright 2019 by the Association of Urological Surgery / Journal of Urological Surgery published by Galenos Publishing House. 


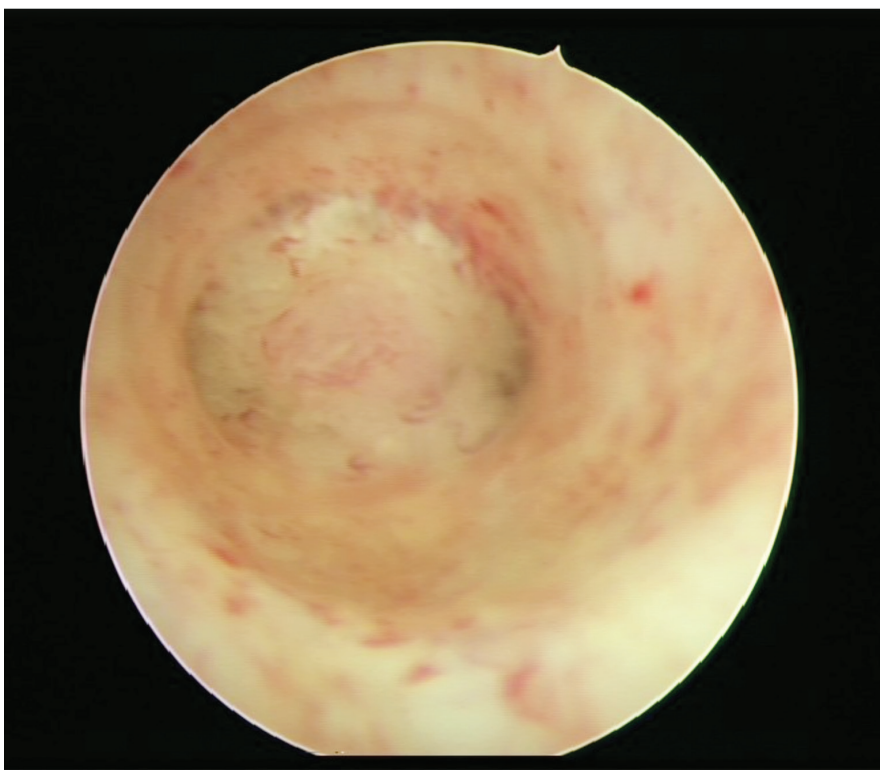

Figure 1. Rigid cystourethroscopy showing urethral lumen occluded by tumour

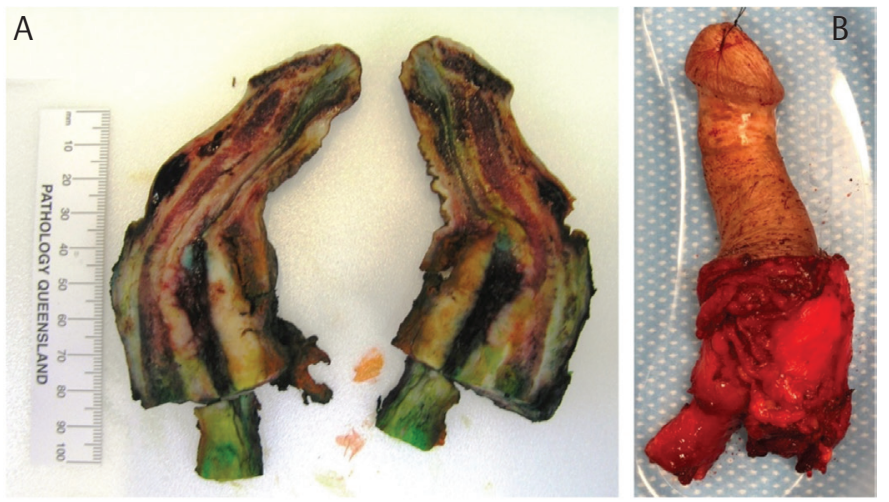

Figure 2. A) Macroscopic appearance of radical penectomy and urethrectomy specimen, with tumour invading corpus spongiosum and corpus cavernosum. B) Haematoxylin and eosin-stained section showing urothelial carcinoma with squamous differentiation

segment from penoscrotal junction into mid-bulbar urethra. Erythematous regions within the bladder were biopsied at the posterior, left and right walls. The urethral tumour was further debulked and diathermied, and the catheter was replaced.

\section{Discussion}

Histology confirmed papillary and endophytic high-grade urothelial carcinoma with some squamous differentiation, invading muscularis propria. The bladder biopsies contained only cystitis cystica and mixed inflammation in the lamina propria. Repeat voided urine cytology yielded atypical urothelial cells. CT abdomen/pelvis had no suspicious lymphadenopathy.

With confirmation of invasive urothelial carcinoma, the patient then proceeded to radical penectomy, urethrectomy and perineal urethrostomy. He recovered well and a catheter was left in situ for six weeks. Histology showed pT3 high-grade urothelial carcinoma, arising at the penoscrotal junction 65 millimetres from the urethral meatus, invading into the corpus spongiosum and corpus cavernosum (Figures 2A, 2B). Margins were clear.

\section{Ethics}

Informed Consent: Consent form was filled out by all participants.

Peer-review: Externally peer-reviewed.

\section{Authorship Contributions}

Concept: M.S., D.D., Design: M.S., D.D., Data Collection or Processing: M.S., D.D., Analysis or Interpretation: M.S., D.D., S.M., Literature Search: M.S., Writing: M.S.

Conflict of Interest: No conflict of interest was declared by the authors.

Financial Disclosure: The authors declared that this study received no financial support.

\section{References}

1. Kim SJ, MacLennan GT. Tumors of the male urethra. J Urol 2005;174:312.

2. Gillitzer R, Hampel C, Wiesner C, Hadaschik B, Thuroff J. Single-institution experience with primary tumours of the male urethra. BJU Int 2008;101:964968.

3. Sumino $Y$, Emoto $A$, Satoh $F$, Nakagawa $M$, Mimata $H$. Transitional cell carcinoma of the navicular fossa detected human papillomavirus 16 . Int J Urol 2006;13:645-647.

4. Resnick MJ, Wein AJ. Transitional cell carcinoma of the fossa navicularis in a man with preexisting adenocarcinoma of the prostate. Urol Int 2006;76:186-188.

5. Youshya S, Purdie K, Breuer J, Proby C, Sheaf MT, Oliver RT, Baithun S. Does human papillomavirus play a role in the development of bladder transitional cell carcinoma? A comparison of PCR and immunohistochemical analysis. J Clin Pathol 2005;58:207-210. 